\title{
Morbidity, mortality and mid-term follow-up in patients developing renal insufficiency after on-pump and off-pump coronary surgery
}

\author{
K Ergunes ${ }^{*}$, L Yilik, B Lafcı, E Celik, S Yazman, U Yetkin, T Goktogan, A Gurbuz \\ From 23rd World Congress of the World Society of Cardio-Thoracic Surgeons \\ Split, Croatia. 12-15 September 2013
}

\section{Background}

We aimed to investigate factors affecting morbidity, mortality and survival in patients developing renal insufficiency after on-pump and off-pump coronary surgery.

\section{Methods}

Between January 2002 and December 2009, 2034 patients underwent isolated on-pump and off-pump coronary revascularization in our clinic. Sixty-five patients were having postoperative renal insufficiency. The incidence of postoperative renal insufficiency determined as $3.4 \%(\mathrm{n}=57)$ after on-pump and $2.1 \%(\mathrm{n}=8)$ off-pump coronary revascularization.

\section{Results}

Age, diabetes, preoperative renal insufficiency, and prolonged cardiopulmonary bypass time $(\mathrm{CPB})$ were the independent predictive factors of postoperative renal insufficiency in patients undergoing on-pump coronary revascularization. Postoperative mortality rate was $12.5 \%$ (no $=1)$ and $47.4 \%(\mathrm{n}=27)$ in patients with postoperative renal insufficiency undergoing off-pump and onpump coronary revascularization, respectively $(\mathrm{P}=$ 0.124 ). Mean follow-up was $47.00 \pm 23.08$ months and $44.97 \pm 20.96$ months in patients with postoperative renal insufficiency undergoing off-pump and on-pump coronary revascularization, respectively. In follow-up, mortality rate was $37.5 \%(\mathrm{no}=3)$ and $12.5 \%(\mathrm{n}=7)$ in patients with postoperative renal insufficiency undergoing off-pump and on-pump coronary revascularization, respectively $(P=0.098)$. Diabetes and reoperation for bleeding were the independent predictive factors of

\footnotetext{
* Correspondence: kazimergunes@yahoo.com

Izmir Katip Celebi University Ataturk Training and Research Hospital,

Department of Cardiovascular Surgery, Izmir, Turkey
}

survival in patients with postoperative renal insufficiency undergoing on-pump coronary revascularization.

\section{Conclusions}

Length of ICU stay and postoperative mortality rate were not significant statistically in patients with postoperative renal insufficiency undergoing off-pump and on-pump coronary revascularization. In follow-up, mortality rate was not significant statistically in patients with postoperative renal insufficiency undergoing off-pump and onpump coronary revascularization.

Published: 11 September 2013

doi:10.1186/1749-8090-8-S1-O211

Cite this article as: Ergunes et al:: Morbidity, mortality and mid-term

follow-up in patients developing renal insufficiency after on-pump and

off-pump coronary surgery. Journal of Cardiothoracic Surgery 2013

8(Suppl 1):0211.

Submit your next manuscript to BioMed Central and take full advantage of:

- Convenient online submission

- Thorough peer review

- No space constraints or color figure charges

- Immediate publication on acceptance

- Inclusion in PubMed, CAS, Scopus and Google Scholar

- Research which is freely available for redistribution

Submit your manuscript at www.biomedcentral.com/submit 